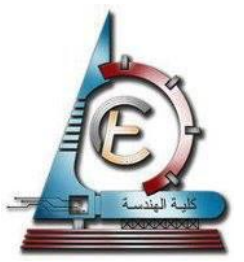

Journal of Engineering Sciences

Assiut University

Faculty of Engineering

Vol. 47

No. 5

September 2019

PP. 706-719

\title{
EFFECT OF DIFFERENT WINDOWS' GLAZING TYPES ON ENERGY CONSUMPTION OF A RESIDENTIAL BUILDING IN A HOT-ARID CLIMATE \\ "Case Study: Residential Building in New Cairo City"
}

Ahmed Atef Faggal ${ }^{1}$, Abeer Mohamed Moustafa ${ }^{2}$, Mohamed Yasser Arafat ${ }^{3}$

1,2 Department of Architecture, Faculty of Engineering, Ain Shams University

${ }^{3}$ Department of Architecture, Canadian International College

Received 21 May 2019; Accepted 3 June 2019

\begin{abstract}
The increasing energy consumption of residential buildings in Egypt which reached about $42 \%$ of total energy consumption in latest energy statistics, affirms the need for energy conscious design of buildings. Many researches aim at guiding new buildings design to be energy-efficient, however, retrofitting existing buildings can result in significant reductions in energy consumption. This paper outlined different window glass types led to a reduction in cooling loads via the building envelope for the existing building. This paper aims to evaluate the effect of changing windows glass types to reduce energy consumption in the hot arid climate of greater Cairo. The energy analysis carried out by employing advanced simulation via DesignBuilder software for a residential building located in Cairo; this case study analyzed the performance of seven different window glass types in a residential building façade in the different cardinal orientations. The model was validated by taking a field measurement to measure and quantify the temperature of a selected room taken within three consecutive days in May and June 2019 and compared to the simulation tool results, the average error percentage was $2.15 \%$. The results of the simulation showed that changing glass type can reduce energy consumption by up to $18.8 \%$, indicating the significance of energy efficient retrofitting of existing residential buildings.
\end{abstract}

Keywords: Energy efficiency, existing residential buildings, energy retrofit, building envelope, fenestration parts, energy analysis.

\section{Introduction}

In the last decade, Egypt has been facing many problems to secure its energy resources that to cover the increasing energy consumption, Egypt now is trying to avoid energy shortages during annual peak periods of demand, which is increasing by $7-10 \%$ per year [1], increasing negative environmental impacts associated with the production and consumption of fossil fuels. Hence, building assessment systems that measure

* Corresponding author.

E-Mail: mohamed_arafat@cic-cairo.com 
sustainability, interaction with the surrounding environment and conservation of natural resources from energy, water, and materials are released.

The increase in the number of people, which is offset by a faster increase in the number of residential buildings that consume more than $42 \%$ of energy [2] and 35\% of consumption used by the air conditioning, where temperatures in Cairo in July 2018 reached 45 C. Sales of air conditioning sets increased from 54,000 units in 1996 to 766,000 in 2010 [1] and increased by $70 \%$ in 2018 . Such remarkable increases promote more attention and efforts to adopt more energy-conscious design approaches of buildings to reduce the need for cooling or air conditioning as a major energy consumer in buildings located in hot areas.

The existing buildings' envelope stock represents the most significant potential for energy savings [3]. The building envelope is the largest thermal collector for a building. Existing Buildings' envelope represents the most significant potential for energy savings; it can save more than $30 \%$ of total building energy consumption [4]

The fenestration parts of the envelope strongly influence annual heating and cooling loads; it has been estimated that fenestrations account for nearly $25 \%$ of energy use in a typical residential building [5].

In order to reduce heating and cooling loads in buildings through fenestration systems, the ability to control heat flow through fenestration is essential. This goal is accomplished using various treatments such as spectrally selective coatings, tints, insulating gas sandwiched between panes, improved frames, intelligent coatings, replacing the window and controlling of air leakage.

Energy consumption in residential buildings count for over $40 \%$ of total energy consumption in Egypt [2], heating and cooling loads only represent about one-third of all energy consumed by a building.

Retrofitting of existing residential buildings bears the important potential to reduce national energy consumption in the residential building stock of Egypt.

\subsection{Research problem}

The research problem lies in the process of finding the appropriate glass type for existing residential buildings' envelope which represent the largest sector of energy consumers in Egypt in the presence of several determinants in the building and surrounding environment that make it difficult to adapt to the task of reducing energy consumption.

\subsection{Research aim}

This paper aims to evaluate the effect of changing windows glass types to reduce energy consumption in the hot arid climate of greater Cairo.

\subsection{Research Hypothesis}

The main premise of the study is that energy consumption in existing residential buildings can be reduced by some simple, cost-effective glass types applied to the building envelope by up to $18 \%$, thereby reducing the national energy consumption of residential buildings.

\subsection{Research methodology}

This research is based on a set of research approaches: 


\subsubsection{Analytical approach}

Analytical study of glass types used in residential buildings and the conclusion of some previous studies and their findings about reducing energy consumption.

\subsubsection{Applied methodology}

The practical approach was done through the use of a computer program specialized in the simulation of energy consumption "DesignBuilder", the simulation applied to the model of a residential apartment in New Cairo city and the assessment of the current building situation was held through a comprehensive survey of elements, components, and systems of the building used. After the addition of different glass types and write the results of each element separately and make comparison of them in terms of the energy efficiency the researchers recommended optimal glass types "according to previous results" that can reduce energy consumption by up to $18 \%$.

\section{Window glazing types}

Window consist of glass panes, spacers, structural frames, and sealants, as shown in Figure (1). Recently, the variety of glass types, coatings, and frames available for use in window systems has increased significantly.

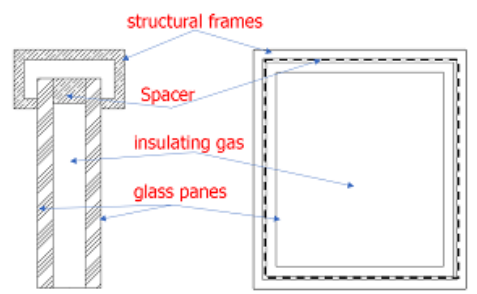

Fig. 1. The components of the window - Researcher

in order to study and analyses window glazing thermal characteristics, the following terms must be understood "Fig 2"

- Solar Heat Gain Coefficient (SHGC)- the portion of solar radiation entering the space through the fenestration, which is released as heat into space, SHGC is expressed as a number between 0 and 1, lower SHGC is better [6]

- U-Value/ Thermal transmittance- a measure of the heat transmission through the fenestration, the lower the U-value is more efficient, the unit of measurement is $\mathrm{W} / \mathrm{m}^{2} \mathrm{~K}$ [6].

- R-value- is the converse of thermal transmittance or the ability of a material to resist heat flow, the unit of measurement is $\mathrm{K} \mathrm{m}^{2} / \mathrm{W}$ [7].

- Visible Light Transmission- The visible light percentage which is transmitted through the glass. The higher the VLT percentage, the more daylight. Also known as $\mathrm{Tv}$, Tvis, and LT. it is also measured in between the range of $380-780 \mathrm{~nm}$ wavelength perpendicular to the surface [8].

\section{1. single-pane windows}

Single pane windows have one layer of glass that offers wind protection and an overall heat transfer coefficient $\mathrm{u}$-value around $5.5 \mathrm{~W} / \mathrm{m}^{2} \mathrm{~K}$ which represents a relatively high value and consequently low thermal insulation. Clear glass also transmits between approximately 70 and 90 percent of the received solar radiation [5]. 


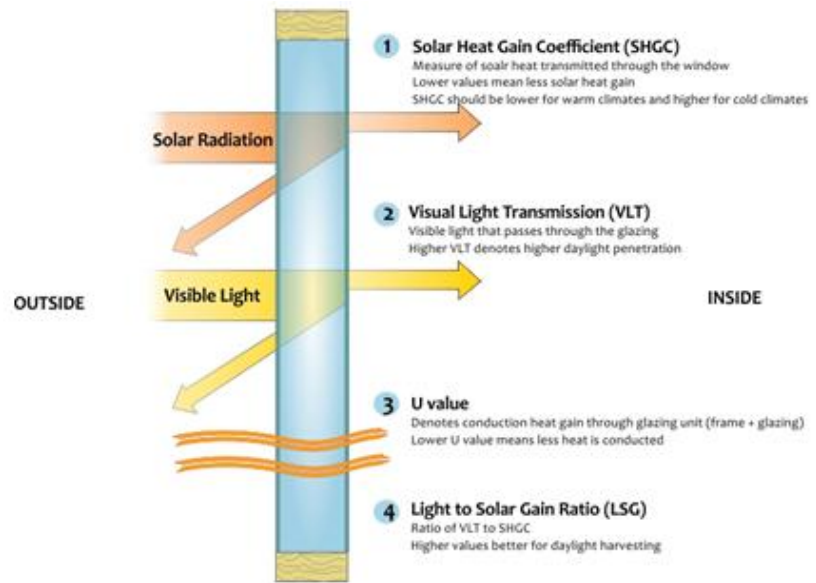

Fig. 2. fenestration envelope thermal characteristics [9]

\subsection{Double-pane windows}

Double-pane windows contain two panes of glass separated by a space of air or gas that helps to reduce the transfer of heat and cold as shown in Figure (3). Double-pane windows are more expensive than single-pane windows, but the running cost will be reduced by using two panes glass [10]. Double-pane windows can reduce cooling energy usage by $18 \%$ during the summer [10] according to less solar radiation transferring through the windows.

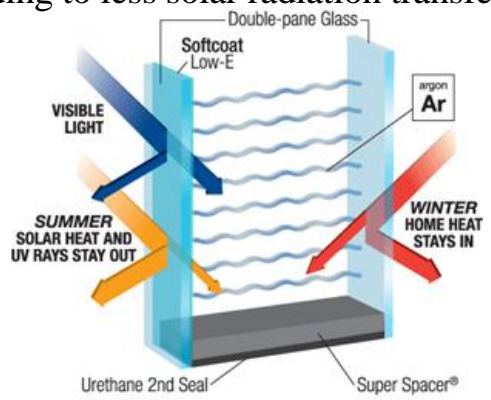

Fig. 3. Double-Pane Window [10]

Forughian et al. [11] Made a comparative study of using single-glazed windows "3 mm clear" and double-glazed Windows " $3 \mathrm{~mm}$ clear $-13 \mathrm{~mm}$ air $-3 \mathrm{~mm}$ clear" in Terms of Energy Efficiency applied to a residential building facing north and south only and was located in Iran using design-builder software, , the simulation results showed that the total energy consumption of the residential unit decreased from $14559 \mathrm{Kwh}$ while using single glass pane to $12755 \mathrm{Kwh}$ while using double glass panes, based on that, replacing single glass panes to double glass panes can save around $12.3 \%$ from total building energy consumption.

\subsection{Tinted glass}

Tinted glass reduces the heat and light transfer to indoor through absorbing incoming solar radiation through the glass as shown in Figure (4). Gray, bronze, blue and green tinted windows all reduce the penetration of both light and heat into buildings with almost same reflectance percentage but the Solar Heat Gain Coefficient of the grey is the lower one which provides better thermal performance [12], the numerical value of reflectance and absorption varied according to different glass types. Visible light penetration through green and blue compared with other tinted windows offer greater penetration of visible 
light and reduce heat transfer less than other colors. Gray and bronze provide natural colors on the interiors. Heat transfer is not reduced through clear glass without special tints.

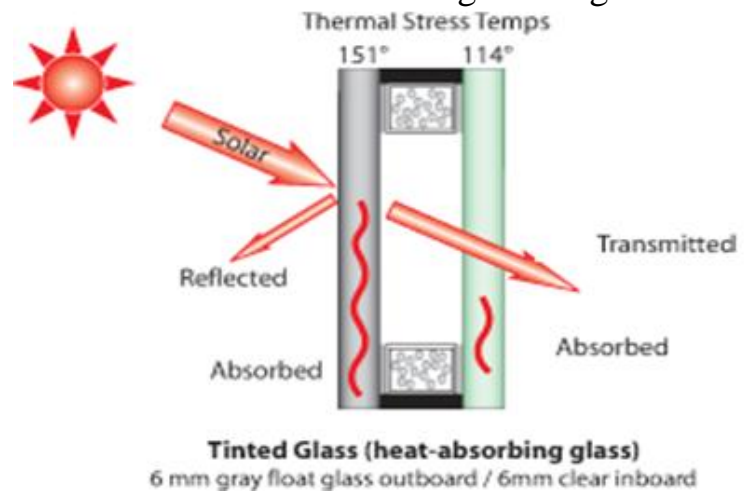

Fig. 4. Tinted glass [12]

\subsection{Low-Emissivity (Low-E) coating}

The low-E glass was created to minimize the amount of infrared and ultraviolet light that penetrates the glass, without minimizing the amount of light that transmitted. Low-E glass windows are microscopically thin metal or metallic oxide coating that is transparent and reduces the emission of radiant heat. The Low-E coatings can keep heat inside a house in cold weather and can reflect heat outside a house in hot weather [13]. Coated glass range is divided into two main categories which refer to "Passive Low-E Coatings (Hard-Coat)" and "Solar Control Low-E Coatings (Soft-Coat)" coatings for different weather conditions [14]. The passive Low-E coatings layer applied to the glass ribbon while it is being manufactured on the float line, that causes the coating to combine to the hot glass surface [15]. This combination creates a strong bond, or "hard-coat," which is very durable, Solar control Low-E coatings are produced using the Magnetron Sputtering Vapor Deposition (MSVD) process, which means the coating is applied off-line to pre-cut glass in a vacuum chamber at room temperature. This coating referred to as "soft-coat," which has lower emissivity and offers the highest performing solar control [15].

\section{Case Study: Residential building in New Cairo city}

According to World Bank statistics [16], 92.5\% of Cairene families are living in linear apartment blocks [17]. Just by walkthrough Cairo, it is noticeable the spread of linear apartment blocks, especially in new cities which are called $3^{\text {rd }}$ generation cities [18]. Linear apartment blocks are a comprehensive local typology which promoted lower density along with new urban communities compared to tower blocks in Egypt. However, apartments in this type of buildings consume more energy than apartments in compacted fabric or towers [17] where The climate of Cairo is classified as hot and arid climate or desert climate [19].

The housing sector in Egypt is dominated by private owners "real estate companies, individual persons, and investors" and government agencies, as an example; number of apartments only in New Cairo city in 2019 is 306827 units, 49226 units are delivered by the government while 27114 units were provided by third parties and 230,486 by the private sector [18]. Reinforced concrete columns and beam structure system with $12 \mathrm{~cm}$ exterior clay brick walls are the dominant method used for residential construction. Glass windows usually have aluminum frame and the glass is usually single clear fragile glass. 
The case study was selected in the New Cairo city due to the availability of building regulations, as all the third generation cities in Egypt, which ensures that there is a minimum limit for the common factors to all residential buildings constructed in the city according to the building requirements and laws such as overhang depth limitation, setbacks, buildings heights, built up area ratio to net area and sometimes the materials of construction and finishing, but there are no specific regulations about the glass type.

By making an interview with the engineering department in the Development Authority of New Cairo City they clarify that this kind of buildings are the common prototype of New Cairo city, especially the residential sector in New Cairo city is driven by the private sector which is controlled by few companies with design limitation [20].

\subsection{Climate analysis}

The climate of Cairo is classified as hot and arid climate or hot desert climate, while weather is generally warm, sunny and dry year-round, Cairo is in the second climate zone according to Egyptian Code for Improving Energy Efficiency in Buildings [21]. The values of monthly mean air temperature remain above the annual averages between February and December. The average annual mean air temperature of Cairo is $22^{\circ} \mathrm{C}$. Monthly mean air temperatures range from $14^{\circ} \mathrm{C}$ to $29^{\circ} \mathrm{C}$. The lowest mean temperature is in January, and the highest is in August. The second hottest month is July, with mean temperature $28.5^{\circ} \mathrm{C}$. Also, the observed highest temperature was in July with $44^{\circ} \mathrm{C}$. While the lowest degree was observed in January with $2.5^{\circ} \mathrm{C}$ [22].

\subsection{Methodology}

An inspection for the selected building was held via a simple walkthrough to determine the current situation of the building. Then by using DesignBuilder software, a simulation for the building was held to determine the energy consumption of the building in the four main orientations taking into consideration the surrounding buildings to generalize the result for use in similar prototypes but with a different orientation as shown in Figure (5)
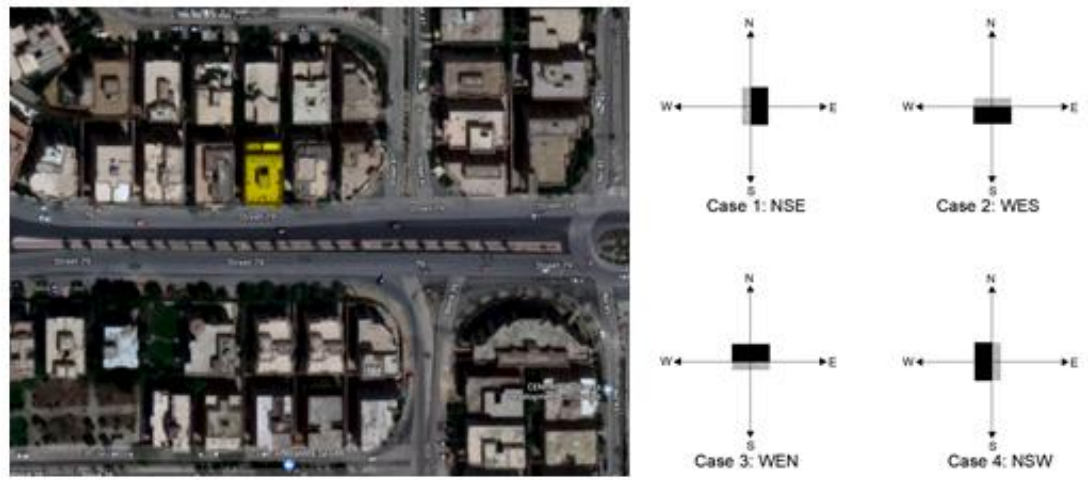

Fig. 5. Base case orientation Researcher

Then the building was simulated after changing the glass type using seven different glass types as described in table (1) 
JES, Assiut University, Faculty of Engineering, Vol. 47, No. 5, September 2019, pp. 706-719

Table 1.

Characteristics of the proposed glazing system -Researcher after DesignBuilder

\begin{tabular}{|c|c|c|c|}
\hline & Glazing type & $\begin{array}{l}\text { U-value } \\
\left(\mathrm{W} / \mathbf{m}^{2} \mathbf{k}\right)\end{array}$ & SHGC \\
\hline single-pane windows & Single 3mm (Base case) & 6.257 & 0.858 \\
\hline \multirow{5}{*}{ Double-pane windows } & Double clear $6 \mathrm{~mm}-13 \mathrm{~mm}$ air & 2.708 & 0.697 \\
\hline & Double blue $6 \mathrm{~mm}-13 \mathrm{~mm}$ air & 2.708 & 0.481 \\
\hline & Double bronze $6 \mathrm{~mm}-13 \mathrm{~mm}$ air & 2.708 & 0.482 \\
\hline & Double green $6 \mathrm{~mm}-13 \mathrm{~mm}$ air & 2.708 & 0.486 \\
\hline & Double grey $6 \mathrm{~mm}-13 \mathrm{~mm}$ air & 2.708 & 0.463 \\
\hline $\begin{array}{l}\text { Tinted glass- Low-Emissivity } \\
\text { (Low-E) coating }\end{array}$ & Double tinted low-e $6 \mathrm{~mm}-13 \mathrm{~mm}$ air & 1.772 & 0.369 \\
\hline
\end{tabular}

\subsection{Model calibration}

Designbuilder is a trusted tool based on Energyplus that is funded by the U.S. Department of Energy Building Technologies Office [17]. It was chosen as a simulation tool due to its accuracy and correspondence to the base case. Designbuilder has a friendly interface and give accurate results in thermal simulation. The highest error rate is 3,5\% and the least error rate is $2,9 \%$,therefore the average rate is 3,17\% [23], which gives a good sign about the data and the ability of using the program in analysis of various alternatives for energy conservation in study case.

The model has reinforced concrete skeleton with clay brick walls, all walls are $0.12 \mathrm{~m}$ thickness with $3 \mathrm{~cm}$ exterior plaster and stucco "Figure (7)" and $2 \mathrm{~cm}$ interior plaster and paintings, the windows are aluminum frames with single $3 \mathrm{~mm}$ clear glass, LED lights are used in all spaces, bedrooms, living room, and reception are actively conditioned using split air condition units. the building information is briefed in Table 2.

The building is located between adjacent blocks of similar physical properties with uniform setbacks between buildings, as shown in Figure (6).

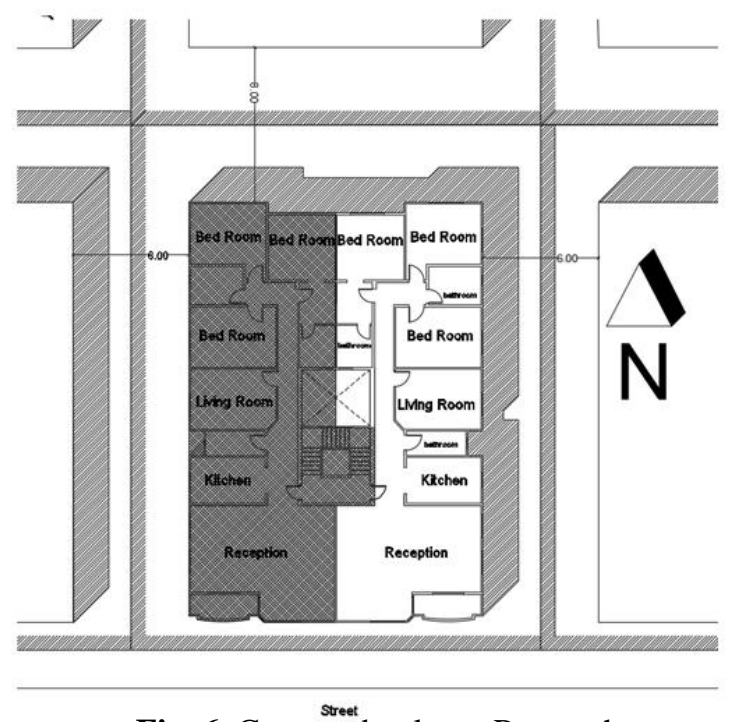

Fig. 6. Case study plan - Researcher 
Table 2.

the information related to the typical apartment- Ref: Researcher

\begin{tabular}{|l|l|}
\hline Height & $3 \mathrm{~m} /$ floor \\
\hline Floor area & $131 \mathrm{~m}^{2}$ \\
\hline Air-conditioned area & $88 \mathrm{~m}^{2}$ \\
\hline External walls Area & $120.3 \mathrm{~m}^{2}$ \\
\hline Glazing Area & $22 \mathrm{~m}^{2}$ \\
\hline
\end{tabular}

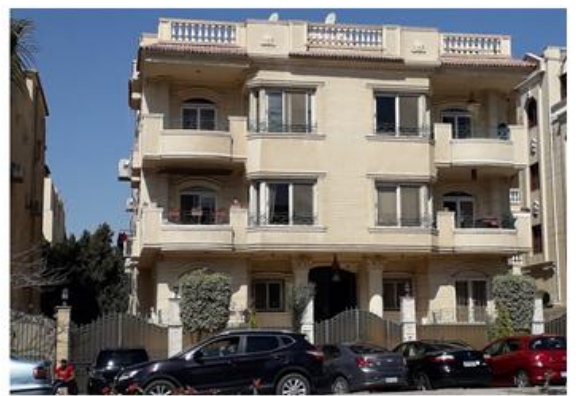

Fig. 7. Case study southern elevation - Researcher

\subsection{Simulated model validation}

Case one "NSE- the current building orientation" was simulated for a complete year (1 Jan- 31 December, 8760 hrs.) and the result was compared to annual electricity bill consumption bills in $\mathrm{kWh}$. The apartment total annual energy consumption was $7497.1 \mathrm{kWh}$, while the electricity bills over one year were $7248 \mathrm{kWh}$ with $3.3 \%$ difference from computational consumption. However, this is an accepted rate of error. Another method was applied to validate the model and simulation tool by taking a field measurement to measure and quantify the temperature of a selected room "Fig. 8 " in the case study to compare it with the results of DesignBuilder. The measurement of temperature fields by digital air temperature meter was carried on the middle of the room by UNI-T UT33 temperature meter.

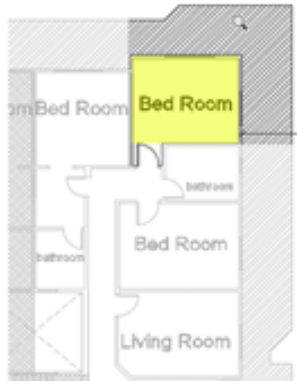

Fig. 8. The Selected room for field measurements - Researcher

The air temperature meter was placed on a stand without operating any machine in the room to avoid heat exchange. Natural ventilation schedule was applied in both the field measurement and in DesignBuilder, the windows were scheduled to be opened when the temperature of the outside was less than the temperature inside the room. The measurements were taken within three consecutive days in May and June 2019. The readings were then recorded, and a comparison was made between the results of the program and the field measurements, as shown in figures 9,10 , and 11 . 


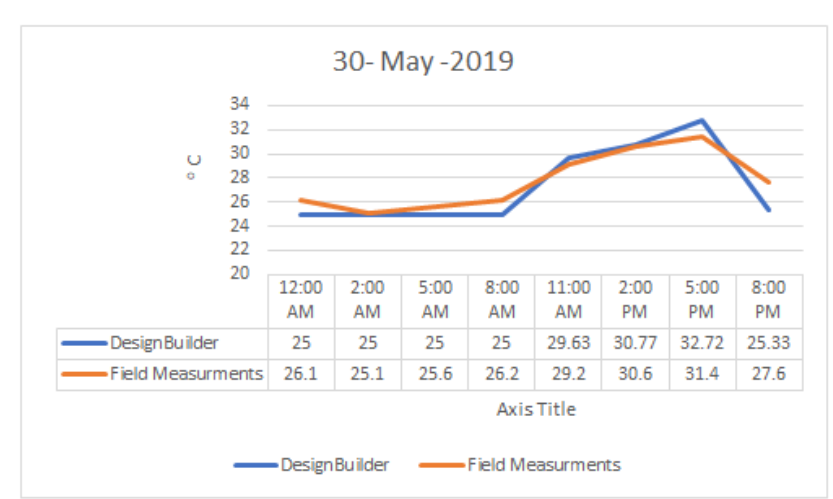

Fig. 9. Comparison between DesignBuilder results and the field measurements on 30 May 2019 - Researcher

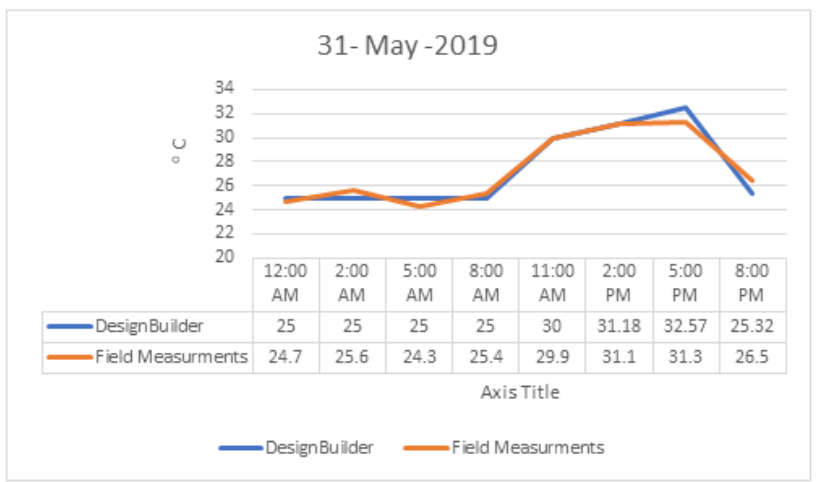

Fig. 10. Comparison between DesignBuilder results and the field measurements on 31 May 2019 - Researcher

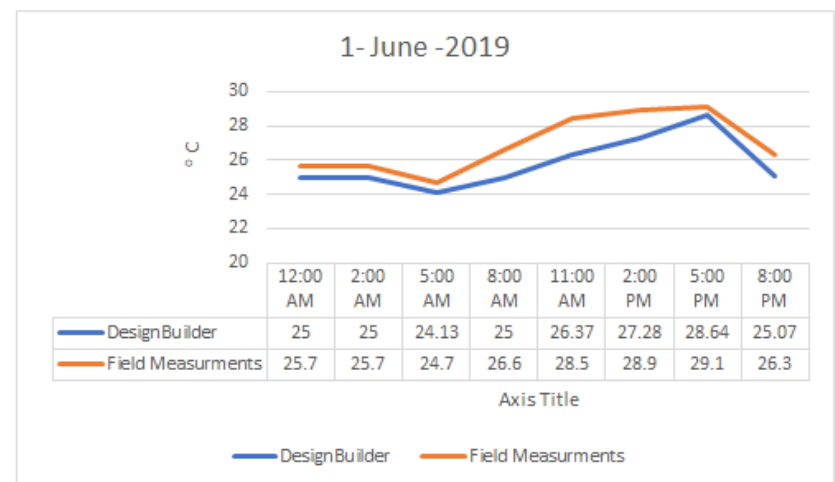

Fig. 11. Comparison between DesignBuilder results and the field measurements on 1 June 2019 - Researcher

The results showed a minor difference between the DesignBuilder Results and the field measurements during the selected three days. For 30 May the average air temperature by DesignBuilder was $27.3{ }^{\circ} \mathrm{C}$, and the filed measurements were $27.72{ }^{\circ} \mathrm{C}$ with error percentage $1.015 \%$. While on 31 May the average air temperature by DesignBuilder was $27.38{ }^{\circ} \mathrm{C}$ and the filed measurements was $27.35{ }^{\circ} \mathrm{C}$ with error percentage $0.12 \%$, and on 1 June the average air temperature by DesignBuilder was $25.8{ }^{\circ} \mathrm{C}$, and the filed measurements were $26.93{ }^{\circ} \mathrm{C}$ with error percentage $4.18 \%$. Therefore, the lowest error percentage was $0.12 \%$ and the highest error percentage was $4.18 \%$ with average of $2.15 \%$.

The difference between the error percentage in electricity bill and the air temperature due to the irregular operation of the air conditioner by the current homeowner, but the 
simulation Assume a regular operation schedule for every space according to its usage and the air temperature inside it.

\subsection{Simulated model performance}

The apartment was simulated for a complete in the main four orientations. For the base case, the simulated energy consumption for the apartment is shown in the Figure (12), the figure shows the consumption results, including heating, cooling, Domestic Water Heating "DWH," equipment, and lighting.

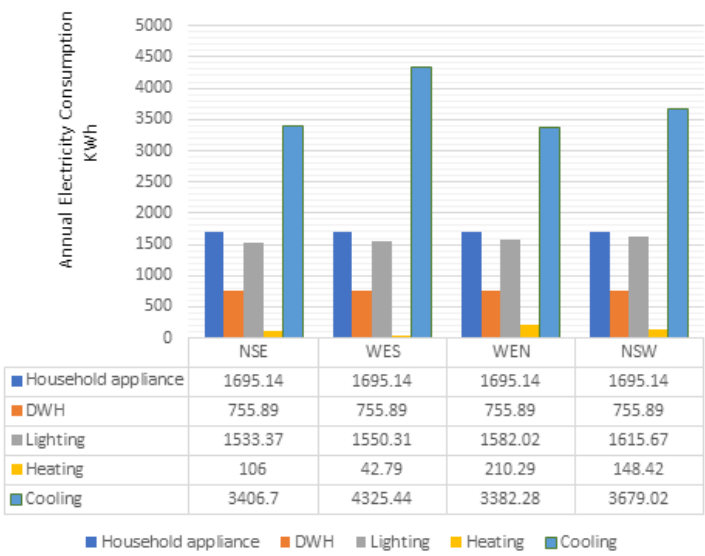

Fig. 12. Base case annual energy consumption (KWh) - Researcher

As figure 12 shows, cooling load represent the higher percentage of energy consumption in all orientations for the chosen cases, For case one "NSE", two "WES", three "WEN", and four "NSW" the cooling load represents 45.44\%, 51.68\%, 44.35\%, and $46.6 \%$ respectively from total apartment energy consumption. While case two "WES" had a higher percentage of cooling load between the other cases.

Figure (13) shows the monthly cooling loads simulated for the base cases; the peak demand was in August for all cases. For case one "NSE", two "WES", three "WEN", and four "NSW" the cooling loads in August are $808.72 \mathrm{kWh}, 931.35 \mathrm{kWh}, 825.11 \mathrm{kWh}$, and $864.24 \mathrm{kWh}$ respectively, but it did not exist in January and almost none in December and February. The highest demand for cooling is in the following four months; June, July, August, and September.

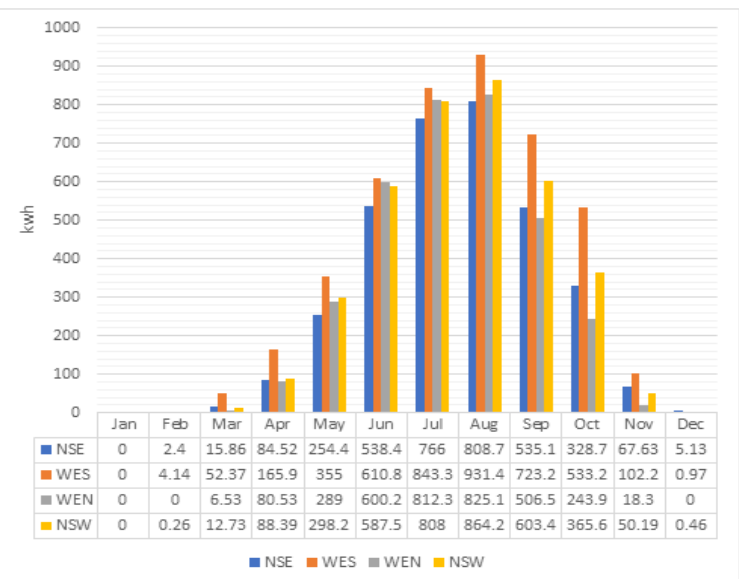

Fig. 13. Base case monthly cooling loads demand - Researcher 


\subsection{Replacing glass panes}

From base case simulation, it was found that it reduces solar gains and increase the resistance via the envelope for cooling load reduction. Base case current windows are $3 \mathrm{~mm}$ single clear glazing and aluminum frame without a thermal break, this has U-value of approximately $6.257 \mathrm{~W} / \mathrm{m}^{2} \mathrm{k}$ and solar heat gain coefficient (SHGC) 0.858 . For the exterior walls, all exterior walls are $12 \mathrm{~cm}$ clay brick walls with $3 \mathrm{~cm}$ outer cement plaster, $2 \mathrm{~cm}$ inner cement plaster, painting from inside and stucco finishing from outside. The exterior walls U-value $2.389 \mathrm{~W} / \mathrm{m}^{2} \mathrm{k}$. The impact of replacing glass panes with double "clear, green, blue, bronze, grey, and tented low-e" $6 \mathrm{~mm}$ glass $-13 \mathrm{~mm}$ air- $6 \mathrm{~mm}$ glass" was investigated then the result has been evaluated, and its relation to cooling load has been recognized.

\section{Results}

By replacing glass panes of the exterior windows by the mentioned glazing systems in table 1, the analysis results of all the proposed glazing system compared to the base case in terms of cooling loads presented in Figure (14). For all orientations, base case "single clear $3 \mathrm{~mm}$ glass" represents the worst case of cooling loads which are 3406.7,4325.44, 3382.28, and 3679.02 KWh For case one "NSE", two "WES", three "WEN", and four "NSW" respectively. However, adding two clear glass panes did not give much effect on cooling loads, it was decreased by $6.8 \%$ in case three with the least result, and the highest percentage reduction in the cooling load's value recorded was $8.03 \%$ for the case number two.

Using tinted blue, green, and bronze $6 \mathrm{~mm}-13 \mathrm{~mm}-6 \mathrm{~mm}$ glass almost give very close results; it varied from $15.48 \%$ to $18.79 \%$ reduction in cooling loads from base case cooling loads in case three and the maximum reduction in cooling loads in case two. While using double grey glass $6 \mathrm{~mm}-13 \mathrm{~mm}-6 \mathrm{~mm}$ give good results; $16.14 \%, 19.53 \%, 15.96 \%$, and $17.00 \%$ reduction from base case are cooling for case one "NSE", two "WES", three "WEN", and four "NSW" respectively. Despite that using double low-e tinted glass 6mm$13 \mathrm{~mm}-6 \mathrm{~mm}$ showed highest energy efficiency from the selected glass panes, it reduced $20.13 \%, 24.40 \%, 20.16 \%, 21.26 \%$ from base case total cooling loads For case one "NSE", two "WES", three "WEN", and four "NSW" respectively.

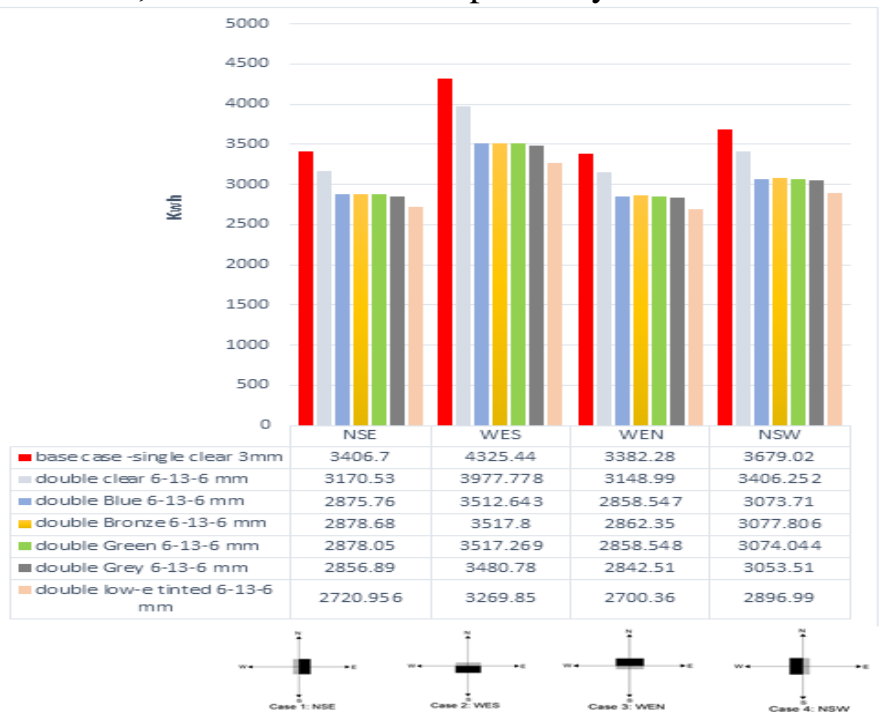

Fig. 11. Building cooling loads in relation to the glazing system - Researcher 


\section{Conclusion}

According to results, the building can consume up to 52\% from its total energy load on cooling load only, so that building envelope impact on energy consumption should not be neglected. Coating the glass can effectively reduce solar transmission through windows and its adverse effect on building energy consumption by using window films and Low-E coating. Single clear $3 \mathrm{~mm}$ glass represents the worst choice for cooling loads demand, adding two clear glass panes did not give much effect on cooling loads than single clear glass, it can decrease cooling load decreased by $8.03 \%$ from the total cooling load demand. Using tinted blue, green, and bronze $6 \mathrm{~mm}-13 \mathrm{~mm}-6 \mathrm{~mm}$ glass almost give very close results, up to $18.79 \%$ reduction in cooling loads from base case cooling loads, while using double grey glass $6 \mathrm{~mm}-13 \mathrm{~mm}-6 \mathrm{~mm}$ give the best results from the selected glass panes up to $19.53 \%$ reduction in cooling loads from base case cooling loads.

\section{Recommendations}

The framework of this research focused on the application of the different glass types on one apartment envelope model in four different orientations. Therefore, in the coming researches, it is recommended to change the base case of the test sample to deep understand the results and try to generalize the results with uncertain parameters and the research should consider the current prices of materials, the availability of technology and the electricity prices and not just design based on energy simulation.

It is noticed that during the simulation that some of the tinted glass affect negatively on natural lighting, therefore, increase artificial lighting load demand; however it acts better with cooling load reduction, so for best results, it should be taken in consideration the effect of changing glass panes on natural lighting.

\section{REFERENCES}

[1] Shady Attia,Arnaud Evrard,Elisabeth Gratia, "Development of benchmark models for the Egyptian residential buildings sector," Elsevier, vol. Applied Energy , no. 94 , p. 270-284, 2012.

[2] E. E. H. Company, "Egypt Electricity Holding Company Annual Report," [Online]. Available: http://www.moee.gov.eg/test_new/PDFReports/REP2016-2017.pdf. [Accessed 17 May 2019].

[3] F. Stazi, Thermal Inertia in Energy Efficient Building Envelopes, Mathew Deans, 2017.

[4] Constantinos BalarasPopi DroutsaPopi DroutsaAthanassios A. ArgiriouAthanassios A. ArgiriouD. N. AsimakopoulosD. N. Asimakopoulos, "Potential for energy conservation in apartment buildings," Energy and Buildings, pp. 143-154, 2000.

[5] Joseph Petersen, Katherine Cort, Sarah Widder, Pacific Northwest National Laboratory, "Mind the Gap: Summary of Window Residential Retrofit Solutions," ACEEE, 2016.

[6] A. Brousseau, "2016 Energy Standards," California Energy Commission, California, 2017.

[7] U. D. o. E. (DOE), "Insulation," [Online]. Available: https://www.energy.gov/energysaver/weatherize/insulation. [Accessed 18 October 2018].

[8] "PERFORMANCE DATA : TERMINOLOGY," metroglass, [Online]. Available: https://www.metroglass.co.nz/catalogue/105.aspx. [Accessed 25 November 2018].

[9] n. z. e. b. (NZEB), "Fenestration," [Online]. Available: http://www.nzeb.in/knowledgecentre/passive-design/fenestration/. [Accessed 18 December 2018]. 
[10] "The Benefits of Replacement Windows with Double-Pane Glass," [Online]. Available: https://www.stanekwindows.com/the-benefits-of-replacement-windows-with-double-paneglass.aspx. [Accessed 30 November 2018].

[11] Samaneh Forughian, Masoud Taheri Shahr Aiini, "Comparative Study of Single-glazed and Double-glazed Windows in Terms of Energy Efficiency and Economic Expenses," Journal of History Culture and Art Research, vol. 6, no. 3, pp. 879-893, 2017.

[12] G. SunGuard, "Advanced architecture glass- Technical information," Guardian Glass, LLC , Michigan, 2018.

[13] Jeffrey Rissman, Hallie Kennan, "low-emissivity Windows," American Energy Innovation Council , 2013.

[14] A. Tahouri, "Evaluation of Windows and Energy Performance Case-Study: Colored Building," Faculty of Architecture (EMU), 2015.

[15] S. Windows, "What is Low-E Glass \& Does it Make Windows Energy Efficient?," 14 February 2017. [Online]. Available: https://www.stanekwindows.com/what-is-low-e-glassand-does-it-make-windows-more-energy-efficient.aspx. [Accessed 8 December 2018].

[16] Feng Liu, Anke S. Meyer, and John F. Hogan, "Mainstreaming Building Energy Efficiency Codes in Developing Countries," World Bank Publications, September 2010.

[17] Mohamed Edeisy, Carlo Cecere, "Envelope retrofit in hot arid climate," in International Conference on Sustainable Synergies from Building to the Urban Scale, SBE 16, Thessaloniki, Greece, 2017.

[18] N. U. C. Authority, "New Cairo," [Online]. Available: http://www.newcities.gov.eg/know_cities/New_Cairo/default.aspx. [Accessed 2 Mars 2019].

[19] CLIMATE-DATA.ORG, "CLIMATE CAIRO," [Online]. Available: https://en.climatedata.org/africa/egypt/cairo-governorate/cairo-3392/. [Accessed 16 May 2019].

[20] E. D.-. D. A. o. N. C. City," the engineering department in the Development Authority of New Cairo City" Interviewee, [Interview]. 1742019.

[21] H. a. B. N. R. C. (HBRC), Egyptian code to improve energy efficiency in buildings, Cairo: the Egyptian National Housing and Construction Research Center, 2005.

[22] J. Huang, "Egyptian Typical Meteorological Year (ETMY)," U. S. National Climatic Data Center, California, USA..

[23] Ayman M. Ismail, Maged M. Abo Elela and Eman B. Ahmed, "Calibration of "Design Builder program"," Journal of American Science ·, vol. 1, no. 11, pp. 96-102], 2015. 


\title{
تأثير انواع الزجاج المختلفة للنواقذ على استهلاك الطاقة لمبنى سكني في المناخ الحار الجاف

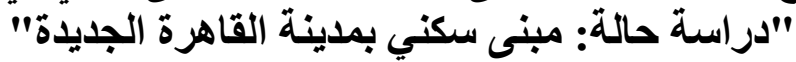

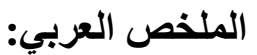

خلال السنوات القليلة الماضية، وصل استهلاك القطاع السكني للطاقة في مصر الى 42\%

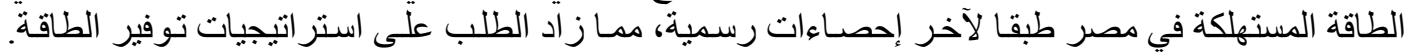

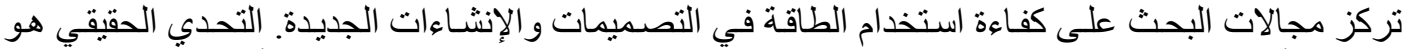

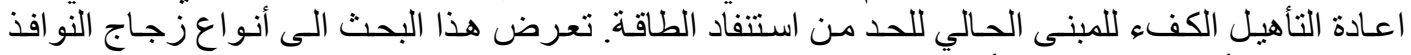

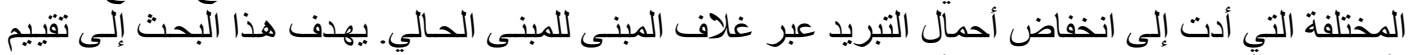

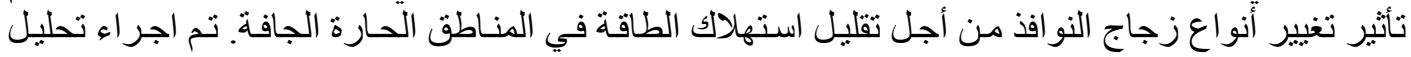

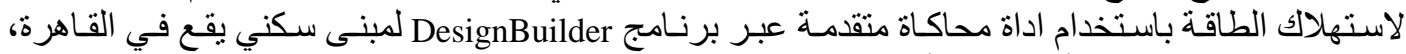

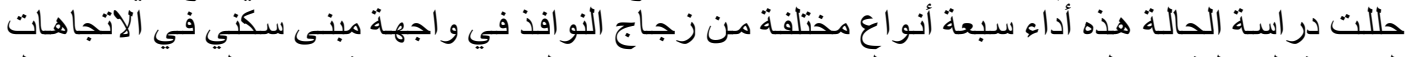

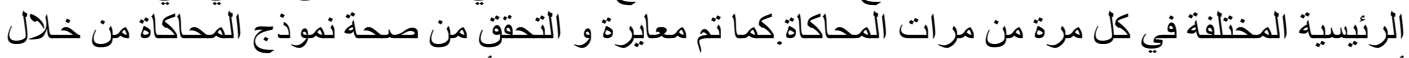

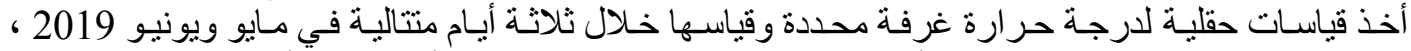

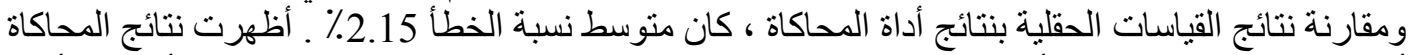

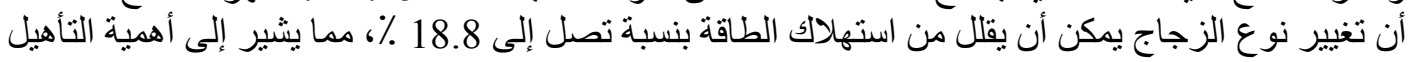
الكفء للطاقة للغلاف الخارجي في المباني السكنية القائمة. 